\title{
PENGEMBANGAN VIDEO PEMBELAJARAN BERBANTU CAMTASIA STUDIO PADA MATERI PERKEMBANGAN TEKNOLOGI KELAS IV SD
}

\author{
Muhammad Abdul Hafizh \\ Surel: Muhammadabdulhafizh28@gmail.com
}

\begin{abstract}
The purpose of this research is to know the feasibility of developing learning media device by using camtasia studio assisted learning video on developmental material of class IV SD. This research is research development or Research and Development, procedure in this research using steps include potential and problem, data collection, product design, design validation, design revision, product trial, product revision. Techniques of data collection using the results of observation, interviews, tests, and documentation. Data analysis technique used is dercriptif qualitative obtained from product quality questionnaire (material expert validation, media expert) in the form of quantitative data, then continued with quantitative descriptive technique using statistical test with test. The conclusions in the results of this study are the effectiveness of learning in the classroom by using camtasia studio-assisted learning videos and products worthy of use.
\end{abstract}

Keywords: Media, $R \& D$, Video

\begin{abstract}
ABSTRAK
Tujuan dari penelitian ini adalah untuk mengetahui kelayakan pengembangkan perangkat media pembelajaran dengan menggunakan video pembelajaran berbantu camtasia studio pada materi perkembangan teknologi kelas IV SD. Penelitian ini adalah penelitian pengembangan atau Research and Development, prosedur dalam penelitian ini menggunakan langkahlangkah meliputi potensi dan masalah, pengumpulan data, desain produk, validasi desain, revisi desain, uji coba produk, revisi produk. Teknik pengumpulan data menggunakan hasil observasi, wawancara, tes, serta dokumentasi. Teknik analisis data yang digunakan adalah derkriptif kualitatif yang diperoleh dari angket kualitas produk (validasi ahli materi, ahli media) berupa data kuantitatif, kemudian dilanjutkan dengan teknik deskriptif kuantitatif menggunakan uji secara statistik dengan tes. Kesimpulan dalam hasil penelitian ini adalah terdapat keefektifitasan pembelajaran dalam kelas dengan menggunakan video pembelajaran berbantu camtasia studio dan produk layak dipakai.
\end{abstract}

Kata Kunci: Media , R\&D, Video

\section{PENDAHULUAN}

Pendidikan merupakan hal yang penting bagi setiap manusia karena dari pendidikanlah seseorang belajar dan menambah informasinya. Pendidikan akan selalu berkembang

Jurusan PGSD Universitas PGRI Semarang 
seiring perkembangan zaman dan membuat pendidikan semakin mempunyai arti untuk sebuah bangsa. Kemajuan sebuah bangsa bisa dilihat dari kualitas pendidikan yang ada di dalamnya. Menurut Undang Undang RI Nomor 20 tahun 2003 tentang Sistem Pendidikan Nasional, pendidikan adalah usaha sadar dan terencana untuk mewujudkan suasana belajar dan proses pembelajaran agar peserta didik mengembangkan potensi dirinya untuk memiliki kekuatan spiritual keagamaan, pengendalian diri, kepribadian, kecerdasan, akhlak mulia, serta keterampilan yang diperlukan dirinya, masyarakat, bangsa dan negara.

Menurut Uno dan Lamatenggo (2011:16) teknologi pembelajaran adalah teori dan praktik dalam desain pengembangan pemanfaatan, pengelolaan serta evaluasi proses dan sumber untuk belajar. Perkembangan teknologi pembelajaran telah memberikan dampak yang sangat signifikan ke semua aspek kehidupan manusia. Perkembangan ini memiliki dampak semakin terbuka dan tersebarnya informasi serta pengetahuan dari dalam negeri sampai ke seluruh dunia menembus batas, jarak, tempat, ruang dan waktu. Pengaruhnya semakin meluas ke berbagai kehidupan, termasuk bidang pendidikan. Realita di lapangan di SD $\mathrm{N}$ Tlogosari Wetan 01 berdasarkan wawancara yang dilakukan dengan guru kelas IV A yaitu Ibu Minarni,
S.Pd permasalahan yang terjadi adalah guru belum memanfaatkan perkembangan teknologi pembelajaran dalam proses pembelajaran. Penggunaan sarana prasarana di kelas pun belum maksimal. Guru dalam mengajarkan materi pelajaran IPS tidak memanfaatkan LCD Proyektor untuk menampilkan media pembelajaran. Faktor ini dikarenakan guru kurang menguasai teknologi sehingga tidak mampu untuk mengembangkan media pembelajaran. Untuk melaksanakan pembelajaran yang menyenangkan dan menarik perhatian siswa, guru harus memilih dan menerapkan gaya mengajar yang bervariasi yaitu salah satunya dengan menampilkan video pembelajaran. Kemampuan video untuk memanipulasi waktu dan ruang dapat mengajak peserta didik untuk berimajinasi ke mana saja walaupun dibatasi dengan ruang kelas. Objekobjek yang terlalu kecil, terlalu besar, berbahaya atau bahkan tidak dapat dikunjungi oleh peserta didik karena lokasinya di belahan bumi lain, dapat dihadirkan melalui media video.

Berdasarkan uraian di atas peneliti menggunakan media pembelajaran berbasis teknologi komputer berupa Video pembelajaran berbantu Camtasia Studio, karena dapat memberikan informasi secara jelas dan tidak menimbulkan kesalahpahaman terhadap materi yang dialami oleh siswa. Kesalahpahaman disini maksudnya 
ketika apa yang dibayangkan dan yang dipikirkan siswa tidak sesuai dengan yang disampaikan oleh guru serta tidak sesuai dengan kenyataan yang ada.

Dari permasalahan tersebut digunakan media pembelajaran berbasis teknologi komputer. Media berbasis teknologi yang berbantu Camtasia Studio ini akan membantu dalam menampilkan suatu objek yang terdapat materi berupa video yang berisi suara berupa instrumental musik dan rangkaian gambar yang terdapat dilingkungan siswa dengan penjelasan berupa tulisan. Sehingga dalam proses pembelajarannya siswa dapat belajar dengan menemukan konsep dengan cara menalar dan menghubungkan pengalaman dan pengetahuannya di kehidupan nyata. Dalam penelitian ini bertujuan untuk Mengembangkan video pembelajaran berbantu Camtasia Studio pada materi perkembangan teknologi kelas IV SD.

Kegiatan belajar dipengaruhi oleh beberapa faktor, Slameto (2010: 54-72) menjelaskan bahwa faktorfaktor yang mempengaruhi belajar ada dua golongan yaitu faktor intern dan faktor ekstern. Faktor intern adalah faktor yang ada dalam diri individu yang sedang belajar, yang tergolong dalam faktor intern yaitu, faktor jasmaniah, faktor psikologis, dan faktor kelelahan. Faktor jasmaniah meliputi faktor kesehatan dan cacat tubuh. Faktor psikologis meliputi inteligensi, perhatian, minat, bakat, motif, kematangan, kesiapan. Faktor kelelahan meliputi kelelahan jasmaniah dan kelelahan rohaniah.

Faktor ekstern adalah faktor yang ada di luar individu. Yang tergolong dalam faktor ekstern yaitu faktor keluarga, faktor sekolah, dan faktor masyarakat. Faktor keluarga meliputi cara orang tua mendidik, relasi antar anggota keluarga, suasana rumah, keadaan ekonomi keluarga, pengertian orang tua, latar belakang kebudayaan. Faktor sekolah meliputi metode mengajar, kurikulum, relasi guru dengan siswa, relasi siswa dengan siswa, disiplin sekolah, alat pelajaran, waktu sekolah, standar pelajaran di atas ukuran, keadaan gedung, metode belajar, tugas rumah. Faktor masyarakat meliputi kegiatan siswa dalam masyarakat, masa media, teman bergaul, bentuk kehidupan masyarakat.

Seseorang yang melakukan kegiatan belajar akan mendapatkan suatu hasil belajar. Menurut Purwanto (2014: 54) hasil belajar merupakan perilaku siswa akibat proses belajar. Perubahan itu diupayakan terjadi di dalam proses belajar mengajar untuk mencapai tujuan pendidikan. Hasil belajar siswa sering digunakan sebagai alat ukur untuk mengetahui seberapa jauh seseorang menguasai bahan yang telah dipelajari.

Menurut Susanto (2014: 137) ilmu pengetahuan sosial, yang sering disingkat IPS, adalah ilmu pengetahuan yang mengkaji 
berbagai disiplin ilmu sosial dan humaniora serta kegiatan dasar manusia yang dikemas secara ilmiah dalam rangka memberi wawasan dan pemahaman yang mendalam kepada peserta didik, khususnya di tingkat dasar dan menengah.

Menurut Banks dalam Susanto (2014: 141) pendidikan IPS atau yang disebut social studies, merupakan bagian dari kurikulum di sekolah yang bertujuan untuk membantun mendewasakan siswa supaya dapat mengembangkan pengetahuan, keterampilan, sikap, dan nilai-nilai dalam rangka berpartisipasi dalam masyarakat, negara, bahkan di dunia.

Menurut Jarolimek dalam Susanto (2014:141) pada dasarnya pendidikan IPS berhubungan erat dengan pengetahuan, keterampilan, sikap dan nilai-nilai yang memungkinkan siswa berperan serta dalam kelompok masyarakat di mana ia tinggal.

Berdasarkan dari pendapat para ahli maka peneliti menyimpulkan bahwa IPS adalah ilmu yang berhubungan dengan manusia dalam semua aspek kehidupan dan interaksinya di masyarakat yang bertujuan mendidik siswa untuk mengembangkan pengetahuan, sikap, dan keterampilan sehingga menjadi anggota masyarakat dan warga negara yang baik.

Menurut Umar dkk. (2007:143) istilah teknologi berkaitan dengan suatu kreasi dan penemuan manusia. Biasanya kreasi dan penemuan tersebut berupa alatalat yang akan memudahkan pekerjaan manusia. Berdasarkan pendapat tersebut, dapat disimpulkan bahwa pengertian teknologi adalah alat yang digunakan manusia untuk memudahkan pekerjaan.

Kustandi dan Sutcipto (2011: 8) mengartikan media pembelajaran adalah alat yang dapat membantu proses belajar mengajar dan berfungsi untuk memperjelas makna pesan yang disampaikan, sehingga dapat mencapai tujuan pembelajaran dengan lebih baik dan sempurna. Berdasarkan penjelasan mengenai arti media pembelajaran menurut Kustandi dan Sutcipto di atas dapat dijabarkan bahwa media pembelajaran merupakan suatu alat yang dapat digunakan guru dalam pelaksanaan pembelajaran yang berfungsi untuk mempermudah penyampaian materi pelajaran sehingga tujuan pembelajaran yang telah ditentukan dapat tercapai secara maksimal.

Video pembelajaran berbantu Camtasia Studio adalah video pembelajaran yang berisi suara berupa instrumental musik dan rangkaian gambar yang terdapat dilingkungan siswa dengan penjelasan berupa tulisan. Penjelasan inilah yang berisi materi-materi pelajaran tentang perkembangan teknologi. Sehingga dalam proses pembelajarannya siswa dapat belajar menemukan konsep dengan cara menalar dan 
Menghubungkan pengalaman dan pengetahuannya di kehidupan nyata.

Video pembelajaran ini dibuat menggunakan bantuan aplikasi Camtasia Studio 8. Menurut Prasetyo Adi (2014:1) Camtasia Studio merupakan salah satu software multimedia yang sering digunakan untuk membuat video, baik berupa untuk editing film ataupun video tutorial. Kemampuan utama Camtasia adalah merekam aktivitas layar desktop secara penuh atau sebagian, dan menyimpan hasil rekaman ke dalam format video. Kemampuan lain dari Camtasia adalah mampu merekam melalui kamera/ webcam. Untuk mengedit video, Camtasia memiliki menu yang lengkap sehingga software ini cukup mudah digunakan untuk seorang pemula sekalipun. Pengguna Camtasia akan sangat leluasa dalam mengedit konten film yang akan dibuat, karena Catamsia mampu digunakan untuk import video, gambar (foto), musik, dan lain-lain. Berikut ini akan ditampilkan beberapa menu penting yang digunakan untuk pembuatan film dalam Camtasia, yaitu: 1) Layar Preview dipakai untuk melihat hasil sementara film yang sedang dibuat. Selain itu, menu ini dapat digunakan untuk mengatur resolusi layar sesuai kebutuhan, 2) Timeline merupakan menu yang digunakan untuk mengatur durasi video.

\section{METODE PENELITIAN}

Jenis penelitian yang digunakan peneliti adalah penelitian dan pengembangan (Research and Development). Menurut Sukmadinata (2015: 164) penulisan dan pengembangan atau Research and Development (R\&D) adalah suatu proses atau langkah-langkah untuk mengembangkan suatu produk baru atau menyempurnakan produk yang telah ada, yang dapat dipertanggungjawabkan. Jenis penelitian dan pengembangan dipilih oleh peneliti, karena peneliti mengembangkan produk berupa media pembelajaran. Media pembelajaran yang digunakan peneliti ini merupakan media pengembangan dari media video yang sudah ada. Penelitian dan pengembangan ini akan menghasilkan media Video Pembelajaran berbantu Camtasia Studio yang memuat materi Perkembangan Teknologi kelas IV SD.

Prosedur dalam penelitian pengembangan ini menerapkan prosedur ADDIE. Menurut Pribadi (2010: 125) model ini sesuai dengan namanya, terdiri dari lima fase atau tahap utama, yaitu (A)nalysis, (D)esain, (D)evelopment, (I)mplementation, dan (E)valuation.

Metode

penelitian pengembangan merupakan metode untuk menghasilkan produk tertentu. Berikut bagan fase model ADDIE menurut Hamdani (2011:169). 


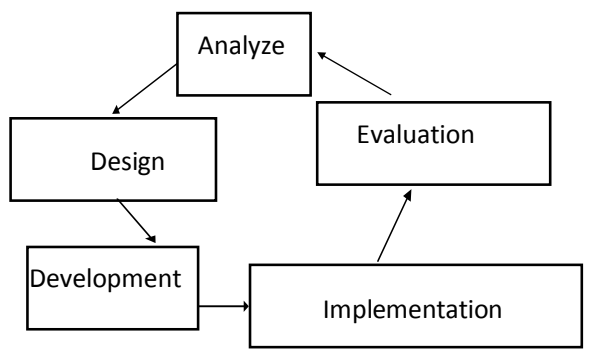

\section{Bagan 3.1 Fase Model ADDIE}

Prosedur pengembangan akan memaparkan prosedur yang ditempuh oleh peneliti dalam membuat produk. Prosedur pengembangan berbeda dengan desain pengembangan dalam memaparkan komponen rancangan produk yang dikembangkan.

Sebagaimana telah dijelaskan pada bagian sebelumya, peneliti menggunakan prosedur model ADDIE. Kelima tahap dalam model ADDIE dilakukan secara sistemik dan sistematis.

Langkah awal yang dilakukan oleh peneliti dalam proses pengembangan adalah mengidentifikasi kebutuhan dan karakteristik siswa. Menurut hasil wawancara dengan guru kelas IV SD N Tlogosari Wetan 01, Ibu Minarni, S.Pd., dalam pembelajaran IPS siswa kurang tertarik dengan pembelajaran yang berlangsung dan siswa kurang berkonsentrasi ketika dijelaskan materi. Siswa cepat bosan karena pembelajaran IPS jarang menggunakan media pembelajaran. Rasa bosan siswa dapat dilihat dari posisi duduk siswa yang mulai membungkuk, kepala ditaruh di atas meja, mata yang mulai sayu, dan siswa yang duduk dibelakang mengobrol dengan teman sebangkunya. Menurut Hamalik (1986) dalam Arsyad (2014: 19), pemakaian media pembelajaran dalam proses belajar mengajar dapat membangkitkan keinginan dan minat yang baru, membangkitkan motivasi dan rangsangan kegiatan belajar, dan bahkan membawa pengaruh-pengaruh psikologis terhadap siswa.

Penggunaan media pembelajaran pada tahap orientasi pembelajaran akan sangat membantu keefektifan proses pembelajaran dan penyampaian pesan dan isi pelajaran pada saat itu. Berdasarkan hasil observasi dan wawancara tersebut dapat dijadikan landasan oleh peneliti dalam pengembangan media video pembelajaran berbantu Camtasia Studio yang dapat digunakan sebagai salah satu alternatif untuk mengajarkan materi kepada siswa secara lebih efektif.

Hasil dari analisis kebutuhan siswa di atas, dapat digunakan peneliti sebagai landasan untuk merancang suatu media pembelajaran yang dapat membuat siswa aktif selama proses pembelajaran. Salah satu alternatif yang dapat diberikan peneliti adalah merancang pembelajaran dengan disertai media pembelajaran, untuk menarik perhatian siswa dalam pembelajaran. Media audio-visual (video) adalah landasan peneliti dalam merancang media video pembelajaran berbantu 
Camtasia Studio. Media ini dapat digunakan untuk menjelaskan materi perkembangan teknologi.

Media video pembelajaran berbantu Camtasia Studio merupakan pengembangan dari media video yang sudah ada dan sudah pernah dilaksanakan dalam media proses belajar mengajar.

Tujuan pengembangan media video pembelajaran berbantu Camtasia Studio adalah untuk mempermudah siswa dalam memahami materi perkembangan teknologi yang disesuaikan dengan kebutuhan dan karakteristik siswa dengan kegiatan pembelajaran yang kreatif, inovatif, aktif, dan menarik.

Mengidentifikasi Standar Kompetensi Dan Kompetensi Dasar Kurikulum KTSP

\section{Tabel Standar Kompetensi dan Kompetensi Dasar}

\begin{tabular}{|c|c|}
\hline A. $S K$ & B. $K D$ \\
\hline $\begin{array}{lr}2 . & \text { Mengenal } \\
\text { sumber daya alam, } & \text { kegiatan ekonomi } \\
\text { dan } & \text { kemajuan } \\
\text { teknologi r di } & \text { lingkungan ran } \\
\text { kabupaten kota dan }\end{array}$ & $\begin{array}{lr}2.3 & \text { Mengenal } \\
\text { perkembangan } & \\
\text { teknologi } & \text { produksi } \\
\text { komunikasi } & \text { dan } \\
\text { transportasi } & \text { serta } \\
\text { pengalaman } & \\
\text { menggunakannya. }\end{array}$ \\
\hline provinsi. & $\begin{array}{l}\text { E. Indikator: } \\
\text { Menjelaskan } \\
\text { pengertian teknologi. } \\
\text { Menyebutkan jenis- } \\
\text { jenis teknologi. } \\
\text { Membandingkan jenis- } \\
\text { jenis teknologi masa } \\
\text { lalu dan masa kini. } \\
\text { Menjelaskan cara } \\
\text { menggunakan } \\
\text { secara sederhana } \\
\text { teknologi masa } \\
\text { lalu dan masa kini. }\end{array}$ \\
\hline
\end{tabular}

Menyusun Rencana Pelaksanaan Pembelajaran (RPP)

Sebelum menyusun RPP, perlu untuk menentukan indikator dan tujuan pembelajaran terlebih dahulu. Indikator perlu disusun setiap KD sehingga dapat dirinci tujuan pembelajaran yang akan dicapai. RPP yang disusun berdasarkan kurikulum KTSP.

Penerapan media video pembelajaran berbantu Camtasia Studio akan dilaksanakan di kelas IV SD N Tlogosari Wetan 01 Kecamatan Pedurungan dengan tujuan untuk menjelaskan materi perkembangan teknologi. Sebelum diuji cobakan media sudah divalidasi. Uji validitas yang dilakukan oleh peneliti meliputi validasi ahli media pembelajaran dan validasi ahli materi pembelajaran. Menurut Sugiyono (2015: 414) menyatakan validasi desain sebagai berikut.

Validasi desain merupakan proses kegiatan untuk menilai apakah rancangan produk, dalam hal ini metode mengajar baru secara rasional akan lebih efektif dari yang lama atau tidak. Dikatakan secara rasional, karena validasi di sini masih bersifat penilaian berdasarkan pemikiran rasional, belum fakta lapangan. Validasi produk dapat dilakukan dengan cara menghadirkan beberapa pakar atau tenaga ahli yang sudah berpengalaman untuk menilai produk bru yang dirancang tersebut. Setiap pakar diminta untuk menilai desain 
tersebut, sehingga selanjutnya dapat dilakukan dalam forum diskusi. Sebelum diskusi peneliti mempresentasikan proses penelitian sampai ditemukan desain tersebut.

Menurut Sugiyono (2015: 414) setelah desain produk, divaliasi melalui diskusi dengan pakar dan para ahli lainnya, maka akan diketahui kelemahannya. Kelemahan tersebut selanjutnya dicoba untuk dikurangi dengan cara memperbaiki desain. Yang bertugas memperbaiki desain adalah peneliti yang mau menghasilkan produk tersebut.

Pada tahap implementasi, bertujuan untuk mendapatkan desain media video pembelajaran dengan berbantuan camtasia yang valid dan baik. Revisi produk dilakukan oleh peneliti secara berkala apabila desain belum mencapai tingkatan valid yang diharapkan. Pihak yang berperan penting pada taahap ini adalah ahli media dan ahli materi pembelajaran yang menentukan apakah desain perlu direvisi atau sudah sesuai. Media video pembelajaran dengan berbantu Camtasia Studio yang sudah direvisi atau diperbaiki selanjutnya diterapkan pada kelas uji coba.

$$
\text { Evaluasi yang dilakukan }
$$
untuk media video pembelajaran berbantu Camtasia Studio bertujuan menyempurnakan produk setelah melalui tahap implementasi. Evaluasi meliputi perbaikan produk yang didapat dari saran pada angket yang diberikan kepada ahli media (dosen) dan ahli materi (dosen IPS dan guru kelas), selanjutnya peneliti dapat memperbaikinya. Efektif atau tidaknya media video pembelajaran berbantu camtasia serta minat siswa terhadap media tersebut dapat dilihat dari angket tanggapan siswa.

Teknik pengumpulan data yang digunakan adalah kuesioner atau angket. Menurut Sugiyono (2015: 199) kuesioner merupakan teknik pengumpulan data yang dilakukan dengan cara memberi seperangkat pertanyaan atau pernyataan tertulis kepada responden untuk dijawabnya.

Data-data yang diperlukan dari responden dapat dihimpun melalui angket atau kuesioner. Angket tersebut berupa pertanyaanpertanyaan tertutup yang diberikan pada responden. Data kuantitatif skor penilaian yang diperoleh dari hasil pengisian angket ahli media pembelajaran dan ahli materi pembelajaran, dianalisis dengan menggunakan skala Likert dan skala Guttman.

Skala likert (Method of Summated Rating) menghadirkan sejumlah pertanyaan positif dan negatif tentang suatu objek sikap. Dalam menjawab butir-butir dalam skala ini subjek memilih: sangat setuju, setuju, ragu-ragu, tidak setuju, sangat tidak setuju: berturutturut diberi skor: $+2,+1,-1,-2$.

Skala

Guttman

mengembangkan teknik untuk mengatasi masalah dari skala likert 
dan Thurstone yang disebut teknik kumulatif. Teknik Guttman ditandai sebagai skala unidimensional, bertujuan menetapkan bahwa sikap yang sedang dikaji hanya melibatkan satu dimensi.

Instrumen penelitian adalah alat atau fasilitas yang digunakan oleh peneliti dalam mengumpulkan data agar proses penelitian lebih mudah dan hasilnya lebih baik. Instrumen yang digunakan dalam penelitian dan pengembangan ini adalah instrumen untuk pengembangan media video pembelajaran berbantu Camtasia Studio pada materi perkembangan teknologi.

Instrumen yang diperlukan dalam penelitian dan dan pengembangan ini, yaitu:

1. Lembar Angket Ahli Media Pembelajaran Dan Guru.

Lembar angket ahli media pembelajaran merupakan lembar angket yang ditujukan kepada dosen Universitas PGRI Semarang yang diminta kesediannya untuk menilai dan memberikan kritik saran tentang media yang dikembangkan dalam penelitian pengembangan. Angket ini disusun menggunakan skala likert (skala bertingkat). Aspek penilaian untuk ahli media yaitu: 1) Penilaian media video pembelajaran berbantu Camtasia Studio, 2) Aspek indikator kesesuaian, 3) Aspek kelayakan produk, 4) Aspek kontribusi produk, dan 5) Aspek keunggulan produk. Dalam masing-masing aspek penilaian angket ahli media terdapat rubrik penilaian dengan kriteria Sangat Setuju, Setuju, Tidak Setuju, dan Sangat Tidak Setuju.

2. Lembar Angket Ahli Materi Pembelajaran Dan Guru Menurut Arikunto (2013:211) validitas adalah suatu ukuran yang menunjukkan tingkat-tingkat kevalidan atau kesahihan sesuatu instrumen. Suatu instrumen yang valid atau sahih mempunyai validitas tinggi. Sebaliknya, instrumen yang kurang valid berarti memiliki validitas rendah. Sebuah instrument dikatakan valid apabila mampu mengukur apa yang diinginkan. Sebuah instrument dikatakan valid apabila dapat mengungkap data dari variabel yang diteliti secara tepat.

Untuk mengetahui validitas item soal digunakan rumus korelasi Product Moment. Rumus korelasi Product Moment sebagai berikut:

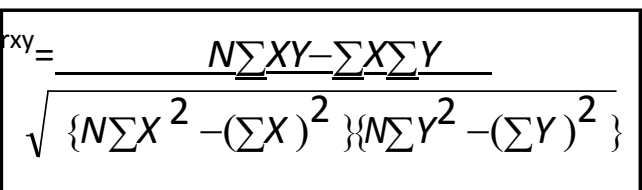

Keterangan:

$r_{x y} \quad$ : koefisien korelasi item soal

$\sum X$ : jumlah skor item soal

$\sum Y$ : jumlah skor total

$N \quad$ : jumlah peserta didik

$\sum X^{2}$ : jumlah kuadrat skor item soal

$\sum Y^{2}:$ jumlah kuadrat skor total 
Harga rxy yang diperoleh dibandingkan dengan $r_{\text {tabel }}$ Product Moment dengan taraf signifikan $5 \%$ jika harga rhitung $>r_{\text {tabel }}$ maka instrument dinyatakan valid. Sebuah tes dikatakan valid apabila dapat mengungkapkan data variable yang diteliti secara tepat dan dapat mengukur apa yang hendak diukur.

Reliabilitas

Menurut Arifin (2011: 258)

reliabilitas adalah tingkat atau derajat konsistensi dari suatu instrument. Reliabilitas tes berkenaan dengan pertanyaan, apakah suatu tes teliti dan dapat dipercaya sesuai dengan kriteria yang telah ditetapkan. Suatu tes dapat dikatakan reliabel jika selalu memberikan hasil yang sama bila diteskan pada kelompok yang sama pada waktu atau kesempatan yang berbeda. Menurut Arikunto (2013: 230-231) untuk mencari reliabilitas dengan rumus $\mathrm{K}-\mathrm{R} 20$.

$$
\text { Rumus : } r 11=k k-1 V t-p q V t
$$

Keterangan:

$r 11$ : reliabilitas instrument

$k$ : banyaknya butir pertanyaan

$V t$ : varians total

$\mathrm{P}$ : proporsi subjek yang menjawab betul pada sesuatu butir

P: banyaknya subjek yang skornya $1 \mathrm{~N}$

$q$ : banyaknya subjek yang mendapat skor $0(q=1-p)$
Tingkat Kesukaran

Menurut Arifin (2011: 272) persamaan yang digunakan untuk menentukan Proportion correct (p) adalah:

$$
\mathrm{P}=B N
$$

Keterangan:

$\mathrm{P}$ : tingkat kesukaran

$B$ : jumlah Peserta didik yang menjawab benar

$\mathrm{N}$ : jumlah peserta didik

Daya Pembeda

Menurut Arifin (2011: 273) perhitungan daya pembeda adalah pengukuran sejajuh mana suatu butir soal mampu membedakan peserta didik yang sudah menguasai kompetensi dengan siswa yang belum/kurang menguasai kompetensi berdasarkan kriteria tertentu. Semakin tinggi koefisien daya pembeda suatu butir soal, semakin mampu butir soal tersebut membedakan antara siswa yang kurang menguasai kompetensi." Untuk menghitung daya pembeda setiap butir soal dapat digunakan rumus sebagai berikut:

$$
\mathrm{DP}=(W L-W H) n
$$

Keterangan :

DP = Daya Pembeda

$\mathrm{WL}=$ jumlah peserta yang gagal dari kelompok bawah

$\mathrm{WH}=$ jumlah peserta yang gagal dari kelompok atas $\mathrm{n}=27 \% \mathrm{x} \mathrm{N}$

Desain model yang digunakan dalam penelitian pengembangan ini 
adalah desain media Video Pembelajaran berbantu Camtasia Studio. Video Pembelajaran berbantu Camtasia Studio adalah video pembelajaran yang berisi suara berupa instrumental music dan rangkaian gambar yang terdapat dilingkungan siswa dengan penjelasan berupa tulisan. Penjelasan inilah yang berisi materi-materi pelajaran tentang perkembangan teknologi. Sehingga dalam proses pembelajarannya siswa dapat belajar menemukan konsep dengan cara menalar dan menghubungkan pengalaman dan pengetahuannya dikehidupan nyata.

Video pembelajaran berbantu Camtasia Studio ini tidak terlalu sulit dalam menggunakannya, hanya memerlukan LCD proyektor untuk menampilkan video pembelajaran yang ditayangkan melalui laptop. Video pembelajaran ini tidak hanya berisi gambar saja melainkan juga berisi suara, sehingga dalam penggunaannya dalam proses pembelajaran memerlukan speaker agar suara dalam video pembelajaran tersebut dapat didengar oleh seluruh siswa.

Dalam penelitian ini, validasi desain dilakukan oleh para ahli, yakni ahli media dan ahli materi pelajaran. Setelah para ahli diberikan lembar validasi maka diperoleh data kualitatif yang berupa kelemahan dan kelebihan produk tersebut, sehingga bisa diketahui kelayakan dari produk tersebut. Produk media Video
Pembelajaran berbantu Camtasia Studio pada materi perkembangan teknologi sebagai hasil dari pengembangan tingkat validitasnya. Tingkat validitas media diketahui melalui hasil analaisis kegiatan uji coba yang dilaksanakan melalui dua tahap, yaitu:

1. Uji Ahli Media Pembelajaran

Uji ahli media pembelajaran dilakukan kepada ahli media yang memiliki pengalaman dan keahlian dalam perancangan dan pengembangan media pembelajaran. Spesifikasi untuk ahli desain media adalah minimal mempunyai gelar $\mathrm{S} 1$ di bidang komputasi bisa dari dosen maupun guru dari sekolahan maupun ahli media yang berpengalaman.

\section{Uji Ahli Materi Pelajaran}

Uji ahli materi pelajaran dilakukan kepada ahli materi pelajaran IPS yang berasal dari dosen maupun guru dari sekolah yang memiliki pengalaman yang tinggi dalam mengajar IPS.

Revisi model dilakukan setelah melakukan validasi dengan ahlinya. Revisi model dilakukan guna menyempurnakan desain yang telah dibuat oleh peneliti. Hal ini dilakukan supaya dalam melaksanakan uji coba, produk akan sempurna dan penyampaian fungsi-fungsi media yang ada dalam produk media video pembelajaran berbantu Camtasia Studio dapat tersampaikan dengan baik. Revisi model dilakukan oleh 
peneliti dengan bimbingan dari validator ahli yang telah ditentukan.

Media pembelajaran yang telah melewati tahap validasi kemudian diuji cobakan. Uji coba dilakukan di kelas IV kepada 5 siswa untuk mengetahui respon siswa terhadap media pembelajaran. Setelah itu diuji cobakan lagi oleh peneliti sebagai penyampai materi pelajaran kepada siswa kelas IV yang berjumlah 25 siswa sebagai subyek penelitian. Menurut Sugiyono (2015: 118) teknik sampling merupakan teknik pengambilan sampel. Teknik sampling yang digunakan dalam penelitian ini yaitu non probability sampling. Adapun non probability sampling merupakan teknik pengambilan sampel yang tidak memberikan peluang atau kesempatan sama bagi setiap unsur atau anggota populasi untuk dipilih menjadi sampel. Sedangkan jenis teknik pengambilan sampling yaitu digunakan dalam penulisan ini adalah sampling jenuh, yaitu semua populasi digunakan sebagai sampel.

Untuk mengetahui efektif atau tidaknya media Video Pembelajaran berbantu Camtasia Studio dalam meningkatkan hasil belajar siswa pada materi perkembangan teknologi. Penelitian ini menggunakan PreExperimental Designs (nondesaigns) dengan desain Pretest One-Group Pretest-Posttest Desaigns. Untuk mengetahui lebaih baik atau tidaknya motivasi belajar dan hasil belajar siswa pada mata pelajaran Matematika antara pembelajaran dengan menggunakan model pembelajaran Think Pair Share dengan menggunakan pembelajaran model ceramah. Desain penelitian ini menggunakan Pre-Experimental Designs (nondesaigns) dengan jenis desain One-Group Pretest-Posttest Design. Menurut Sugiyono (2015: 110) jenis One-Group PretestPosttest Design dimana terdapat suatu kelompok diberikan perlakuan, dan diberikan pretest dan posttest pada sebelum dan sesudah pelakuan. Dengan demikian, hasil perlakuan dapat diketahui lebih akurat, karena dapat membandingkan dengan keadaan sebelum diberi perlakuan. Desain ini dapat digambarkan sebagai berikut:

\section{$\mathrm{O} 1 \mathrm{X} \mathrm{O2}$}

\section{Gambar 1: One-Group Pretest-Posttest Desaign.}

Keterangan:

O1 : nilai pretest (sebelum diberi perlakuan)

$\mathrm{O} 2$ : nilai posttest (setelah diberi perlakuan)

Sebelum subyek penelitian mendapatkan materi pembelajaran, siswa diberikan soal tes yang merupakan sebagai Pretest. Setelah siswa selesai mengerjakan soal Pretest, peneliti memaparkan materi pembelajaran dilengkapi dengan 
media Video Pembelajaran berbantu Camtasia Studio. Setelah mempraktikkan pembelajaran, siswa diberikan soal yang merupakan soal Posttest untuk mengetahui seberapa besar keefektivan pembelajaran menggunakan media Video Pembelajaran berbantu Camtasia Studio pada siswa kelas IV SD.

Revisi Model

Revisi model kali ini akan dilakukan apabila dalam ujicoba masih terdapat sesuatu yang harus disempurnakan lagi. Bagian - bagian yang belum baik akan diperbaiki lagi sehingga pengembangan media video pembelajaran berbantu Camtasia Studio ini akan semakin baik.

\section{HASIL DAN PEMBAHASAN}

Sugiyono (2015:96), hipotesis merupakan jawaban sementara terhadap rumusan masalah penulisan, di mana rumusan masalah masalah penulisan telah dinyatakan dalam bentuk kalimat pertanyaan.

Berdasarkan kerangka berpikir di atas, maka hipotesis yang diambil dalam penelitian ini adalah video pembelajaran berbantu camtasia studio efektif terhadap hasil belajar siswa kelas IV SD.

Hipotesis dalam penelitian ini dirumuskan dengan $\mathrm{Ha}$ dan $\mathrm{H} 0$ sebagai berikut:

Ha : Hasil Belajar siswa di kelas yang menggunakan Video Pembelajaran Berbantu Camtasia Studio lebih baik daripada hasil belajar siswa menggunakan

pembelajaran konvensional.

H0 : Hasil belajar siswa di kelas yang menggunakan Video Pembelajaran berbantu Camtasia Studio tidak berbeda dengan hasil belajar siswa yang menggunakan pembelajaran konvensional.

\section{SIMPULAN}

Kualitas produk perangkat pembelajaran video berbantu camtasia studio pada pembelajaran materi perkembangan teknologi adalah baik. Respon siswa terhadap penggunaan video pembelajaran sangat baik. Dan terdapat keefektifitasan yang sangat baik pada kelas saat pembelajaran dengan menggunakan video pembelajaran berbantu camtasia studio.

\section{DAFTAR RUJUKAN}

Adi, Arista Prasetyo. 2014. Menjadi Pembuat Film Andal dengan

Camtasia Studio 8. Jakarta: PT Elex Media Komputindo.

Arifin, Zainal. 2011. Evaluasi Pembelajaran. Bandung: PT. Remaja Rosdakarya.

Arikunto, Suharsimi. 2013. DasarDasar Evaluasi Pendidikan. Jakarta: Bumi Aksara.

Arsyad, Azhar. 2014. Media Pembelajaran. Jakarta: PT Raja Grafindo Persada. 
Hamdani. 2011. Strategi Belajar Mengajar. Bandung: $\mathrm{CV}$ Pustaka Setia.

Kustandi, Cecep dan Bambang Sutjipto. 2011. Media Pembelajaran Manual dan Digital. Bogor: Ghalia Indonesia.

Pribadi, B.A. 2010. Model Desain Sistem Pembelajaran. Jakarta: PT. Dian Rakyat.

Putra, Nusa. 2013. Reseacrh and Development. Jakarta: PT Grafindo Persada.

Slameto. 2010. Belajar \& FaktorFaktor Yang Mempengaruhinya. Jakarta: Rineka Cipta.
Sugiyono. 2015. Metode Penelitian Pendidikan (Pendekatan Kuantitatif, Kualitatif, dan $R \& D)$. Bandung: Alfabeta.

Sukmadinata, Nana Syaodih. 2013. Metode Penelitian Pendidikan. Bandung: PT Remaja Rosdayakarya.

Suparna dkk. 2007. IPS Terpadu Untuk Sekolah Dasar Kelas $I V$. Jakarta: Erlangga.

Susanto, Ahmad. 2015. Teori Belajar \& Pembelajaran di Sekolah Dasar. Jakarta: Prenadamedia Group.

Uno, Hamzah B. dan Nina Lamatenggo. 2011. Teknologi Komunikasi \& Informasi Pembelajaran. Jakarta: Bumi Aksara 